\title{
MOTHER'S FEEDING PRACTICE IN PROVIDING NUTRITIOUS FOOD FOR CHILDREN
}

\author{
Sri Hendrawati ${ }^{1}$, Wiwi Mardiah ${ }^{1}$, Rizky Maudina $^{1}$ \\ ${ }^{1}$ Faculty of Nursing, Universitas Padjadjaran \\ Corresponding email: sri.hendrawati@unpad.ac.id
}

\begin{abstract}
Improper feeding practice in children is one of the causes of nutritional problems in developing countries. This case causes 1.5 million children to die. Feeding practice is a behavior to control the types and the amount of food for children. This study aimed to identify the mother feeding practice to children in the provision of nutrition in a PAUD at Jatinangor sub-district. This study used a descriptive quantitative approach. The population in this study were mothers who had children aged 3-6 years, respondents were chosen using total sampling technique. There were 55 respondents in this study. Data collection used a CFPQ questionnaire (Comprehensive Feeding Practice Questionnaire) to identify the mother's feeding practice. Data were analyzed using the 75 percentile value of the total score of the questionnaire. Data is presented using frequency distribution. The result showed that 39 (70.9\%) mothers had poor feeding practice and $16(29.1 \%)$ mother had good feeding practice. These results illustrate that mother feeding practice is still not appropriate in fulfilling nutrition for children. Nurses as a health worker are expected to improve mothers' knowledge regarding how to apply good and balanced food that appropriate with children's need.
\end{abstract}

Keywords: Children, feeding practice, nutritional status of children.

\section{INTRODUCTION}

According to WHO data (2010) 1.5 million children died from improper feeding. $90 \%$ of these cases occurred in developing countries. Currently, child nutrition problem is a national problem that has not been addressed in Indonesia. One of the reasons is because children experienced rapid physical growth, so they need more nutrition compared to the adulthood growth period (Ningsih \& Kristiawati, 2015).

Children are an age group that is vulnerable to health and nutritional disorders. This is because the immunity, diet, and psychology of a child are still in the development stage (immature) so that the children's quality of life is still depended on their parents, especially mother (Waladow, Warouw, \& Rottie, 2013). Some developing countries experienced malnutrition problems due to inappropriate feeding (Ningsih \& Kristiawati, 2015). Indonesia is one of the developing countries that have considerable nutritional problems. The Global Nutrition Report (2014) reported that Indonesia was the 17th country where there were 3 nutritional problems, namely stunting (short), wasting (thin), and also overweight (obesity).

Data from Riskesdas (2013) also explained that Indonesian children are currently experiencing nutritional problems because 8 out of 100 children in Indonesia are obese. Data from the Indonesian Ministry of Health (2017) showed that in the West Java region there are 
still nutritional problems in children. In 2015 the prevalence of malnutrition in West Java was $3 \%$ and decreased by $0.6 \%$ in 2016 so the prevalence changed to $2.4 \%$. According to data sourced from the Ministry of Health of the Republic of Indonesia (2016), the nutritional problems of children under five in Sumedang Regency are classified as chronic, namely malnutrition by $16.7 \%$, short by $30.7 \%$, thin by $4.0 \%$, and fat by $1.9 \%$. Research by Judistiani et al. (2015) explained that Jatinangor Subdistrict was included in the category of moderate level public health problems. The results of the study showed that the prevalence of underweight in children aged 3-5 years in Mekargalih Village, Jatinangor Subdistrict reached $10.8 \%$ with details of 3 children with malnutrition and 15 children with poor nutritional status.

The factors that cause nutrition problems are divided into 2, namely direct and indirect factors. Direct factors are child food factors, unbalanced dietary nutrition, and infectious diseases. Whereas indirect factors are food availability, environmental sanitation, and parenting methods such as feeding patterns, knowledge, attitudes, skills, and health services (Arifin, 2016; Ministry of Health, 2017; Subarkah, Nursalam, \& Rachmawati, 2016).

Feeding is influenced by culture and social (family and parents). Giving poor quality food will have an impact on the growth and development of children. Providing healthy food can affect children's health in the future. Every child has different nutritional needs depending on the nutritional needs of each age (Gibson et al., 2012).

Feeding practice is defined as behavior with a particular approach that is used to control the selection of food types and the amount of food that children will consume (Dev, McBride, Speirs, Donovan, \& Cho, 2014). Feeding practices implemented by parents aim to control healthy eating behavior for children. The feeding practice is done by controlling the food consumed by children, giving examples to children to consume healthy foods, teaching children to consume nutritious foods so they can encourage them to regulate their nutrition intake independently, helping them to recognize and accept new types of food, and to improve their eating healthy in children (Dev et al., 2014).

Feeding practice can also be interpreted as parents' behavior to influence their child's eating behavior, for example, as parents limiting their children to eat sweet foods (Braden et al., 2014). Musher-Eizenman and Holub's (2007) study explained that the feeding practice to children can be seen from 12 aspects, namely pressure to eat, restriction for weight, food as a reward, emotion regulation, restriction for health, child control, teaching nutrition, encouraging balance and variety, environmentally friendly, involvement, monitoring and modeling. Children's health is the most important thing that must be considered by parents. If the feeding practice is given appropriately and in a balanced manner, it would affect the health status of the 
child. A healthy child can be achieved by providing nutritional needs that are appropriate to the child's needs.

Feeding practice applied by parents can affect children's nutritional status. Perdani and Hasan's research (2016) revealed that there was a relationship between the feeding practice with children's nutritional status as indicated by the results that children who were not optimal in feeding provided by parents had 8 times the chance to have underweight nutritional status compared to parents who pay attention to feeding. appropriately.

Behaviors during the feeding practice taught by parents could influence how children learn to regulate their food intake. Eating a diet that became a habit has the potential to grow a healthy or unhealthy diet in children. If children cannot control and regulate their selves well concerning food the impact can cause obesity and it could possibility continues for a lifetime. The role of parents, especially mothers, is very important about eating in the children's age before they learn to manage their food in the school environment and outside the house (Boucher, 2016).

Parents are responsible for fulfilling child nutrition needs. This role is a background of the feeding practice. The desire to carry out this role can lead to different practices in its application. Parents who are not appropriately applying feeding practices usually always fulfill the child's willingness to consume the various kinds of food they want, or vice versa when parents force children to consume certain foods that parents want (Musher-Eizenman \& Holub, 2007).

Research conducted by Perdani and Hasan (2016) shows that most parents are not optimally carrying out feeding practices on their children. Parents who feed their children by controlling children, involving children in the selection and provision of food, and providing information on food knowledge to their children will support the child's nutritional health.

Parents, especially a mother, have an important role in determining a complete, appropriate and balanced nutrition for children. Children aged 3 years have passive eating habits that are foods eaten by children depended on the food provided by the mother. At this time, children also have a high sense of curiosity, so that mother has the opportunity to introduce various types of food: taste, color, texture, and types of food consumed during the day (Febry \& Marendra, 2008).

Feeding practice in children includes variety and nutritious food preparation and provision (Sholikah, Rustiana, \& Yuniastuti, 2017). Parents must acknowledge that children aged 3-6 years have diverse food sources. Carbohydrates needed by a child are obtained from foods derived from rice, potatoes, rice noodles, noodles, potatoes, rice noodles, noodles, pasta, bread, cakes, wheat biscuits. Sources of protein can be obtained from eggs, tempeh, tofu, fish 
and chicken meat, milk, cheese, beans. Usually to attract children to eat more taste by processing these ingredients into food in the form of nuggets or sandwiches. Vitamins, minerals, and fiber needed by children from fruits (papaya, apples, bananas, melons, oranges, and other fruits) and vegetables are obtained from carrots, spinach, kale, pumpkin, beans, and others (Soenardi, 2005; Sutomo \& Anggraini, 2010).

The researcher conducted a preliminary study in Al-Amanah PAUD and Permata Bunda PAUD which had the highest number of students in Jatinangor District. The place is located near the UNPAD Jatinangor campus and has numerous problems related to feeding practices so that researchers conduct a preliminary study visit to the two places. The results of interviews with 8 mothers found that most mothers rarely bring food supplies for their children and tend to offer their children for snacks at school. Snacks are usually consumed by children when in school in the form of sweets, ice cream, light snacks, gelatin, chocolate, and flavored drinks.

Parents, especially mothers, must acknowledge and pay attention to the application of proper feeding practice to children so that children feel happy when eating and children's appetite increases. Currently, the role of health workers, especially a nurse, can influence the parents so that they can provide children with food, focusing on the needs of the body, not just following the child's desired diet. The purpose of this study was to identify mother's feeding practices in providing nutrition to children in early childhood education (ECE).

\section{METHODS}

This study used a quantitative descriptive design. The population in this study were all mothers who had children aged 3-6 years who were joining the Early Childhood Education (ECE) in the Jatinangor District. The researcher chose the respondent using the total sampling technique in two ECE Jatinangor District places that had the highest number of students. The number of samples taken by researchers was 55 students Al-Amanah and Permata Bunda ECE.

The variable in this study was feeding practice. The instrument used to measure the variable mother's feeding practice was the Comprehensive Feeding Practice Questionnaire (CFPQ) and the back translation process has been carried out. The instrument consisted of 49 questions accompanied by alternative answers as measured by the Likert scale. The validity value of the CFPQ (Comprehensive Feeding Practice Questionnaire) questionnaire was 0.800.91 and the reliability value of the CFPQ questionnaire was 0.80-0.90 (Doaei, Kalantari, Gholamalizadeh, \& Rashidkhanip, 2013). The feeding practice instrument used in this study was analyzed using a 75 percent value of the total score of the questionnaire. The percentile value used by researchers was 185 . If the total feeding practice score is $<185$ categorized as 
good if the total score feeding practice is $\leq 184$ categorized as poor. This study had passed the ethical test with ethical numbers, 451 / UN6.KEP / EC / 2018.

\section{RESULTS}

The analysis in this study was conducted to identify the frequency distribution of respondents based on maternal feeding practices in the provision of nutrition in Jatinangor District ECD. Characteristics of respondents as follows:

Table 1 Mother's Demographic Characters $(\mathbf{n}=55)$

\begin{tabular}{|c|c|c|c|}
\hline No & Characteristic & Frequency $(f)$ & Percentage (\%) \\
\hline \multirow[t]{11}{*}{1.} & Age & & \\
\hline & Late teenage & & \\
\hline & $17-25$ years & 4 & 7,3 \\
\hline & Early adulthood & & \\
\hline & $26-35$ years & 27 & 49,1 \\
\hline & Late adulthood & & \\
\hline & $36-45$ years & 21 & 38,2 \\
\hline & Early elderly & & \\
\hline & $46-55$ years & 2 & 3,6 \\
\hline & Late elderly & & \\
\hline & $56-65$ years & 1 & 1,8 \\
\hline \multirow[t]{6}{*}{2.} & Education & & \\
\hline & Primary School & 7 & 12,7 \\
\hline & Junior High School & 22 & 40 \\
\hline & Senior High School & 20 & 36,4 \\
\hline & Diploma & 3 & 5,5 \\
\hline & Undergraduate & 3 & 5,5 \\
\hline \multirow[t]{7}{*}{3.} & Occupation & & \\
\hline & Housewife & 42 & 76,4 \\
\hline & Laborer & 1 & 1,8 \\
\hline & Government Employees & 1 & 1,8 \\
\hline & Private Employees & 7 & 12,7 \\
\hline & Entrepreneur & 2 & 3,6 \\
\hline & Others & 2 & 3,6 \\
\hline
\end{tabular}

Table 1 showed that the respondent's age was mostly in the category of early adulthood with a range of 26-35 years, namely 27 people (49.1\%), and the least was at the late elderly with age range of 56-65 years, namely $1(1,8 \%)$. The education level of mothers were mostly junior high school graduates, namely 22 respondents while the education level with diploma and undergraduate graduates was only 3 people (5.5\%). Most of the respondents' occupation were housewives 42 respondents $(76.4 \%)$. 
Tabel 2 Mothers Feeding Practice in Providing Nutrition to Children $(\mathrm{n}=55)$

\begin{tabular}{rcc}
\hline Category & Frequency $(\boldsymbol{f})$ & Percentage (\%) \\
\hline Poor Feeding Practice & 39 & 70,9 \\
Good Feeding Practice & 16 & 29,1 \\
\hline
\end{tabular}

The data presented in Table 2 showed that mother feeding practices with a poor category were 39 respondents $(70.9 \%)$ while the mother feeding practice with a good category was 16 respondents $(29.1 \%)$.

Tabel 3 Mothers Feeding Practice Item in Providing Nutrition (n=55)

\begin{tabular}{llcccr}
\hline No. & \multicolumn{1}{c}{$\begin{array}{c}\text { Item } \\
\text { Feeding Practice }\end{array}$} & \multicolumn{2}{c}{ Poor } & \multicolumn{3}{c}{ Good } \\
\cline { 3 - 6 } & & $\boldsymbol{f}$ & $\boldsymbol{\%}$ & $\boldsymbol{f}$ & $\boldsymbol{\%}$ \\
\hline 1. & Monitoring & 39 & 70,9 & 16 & 29,1 \\
2. & Child Control & 41 & 74,5 & 14 & 25,5 \\
3. & Emotion Regulation & 38 & 69,1 & 17 & 30,9 \\
4. & Environment & 30 & 54,5 & 25 & 45,5 \\
5. & Involvement & 38 & 69,1 & 17 & 30,9 \\
6. & Pressure to eat & 41 & 74,5 & 14 & 25,5 \\
7. & Restriction for weight control & 41 & 74,5 & 14 & 25,5 \\
8. & Food as a reward & 33 & 60,0 & 22 & 40,0 \\
9. & Restriction for health & 34 & 61,8 & 21 & 38,2 \\
10. & Modeling & 36 & 65,5 & 19 & 34,5 \\
11. & Teach and encourage & 41 & 74,5 & 14 & 25,5 \\
12. & Teaching about nutrition & 41 & 74,5 & 14 & 25,5 \\
\hline
\end{tabular}

The data presented in table 3 showed that the highest mother feeding practice items in the category were in child control, the pressure to eat items, restriction for weight control, teach and encourage, and teaching about nutrition by 41 respondents $(74.5 \%)$. Whereas in the highest good category was an environment with 25 respondents (45.5\%).

\section{DISCUSSION}

The results of the data from table 2 showed that the mother's feeding practice is in the poor category was 39 respondents $(70.9 \%)$ and the mother's feeding practice in the good category was 16 respondents $(29.1 \%)$. The data showed that the mother's feeding practice with a poor category was more than the good category so the mother was still not optimal in performing the proper feeding method for the child. 
The data presented in Table 3 also showed that the feeding practice items with the highest poor category were in the items of child control, the pressure to eat, restriction for weight control, encourage balance and variety, and teaching about nutrition by 41 respondents (74.5\%). Whereas in the highest good category there were items in a healthy environment with 25 respondents (45.5\%). Based on these results it can be seen that the lack of control given by the mother in limiting the interlude food according to the wishes of the child, the mother also tends to give pressure when the child only consumes small portions of food so that the child eats all the food provided on the plate. and the amount of food containing high sugar, salt and fat, and the mother is not optimal in providing information about the types of healthy foods and the importance of consuming balanced nutrition in children. While based on good categories, these results have shown that the mother has provided healthy food at home so that children might be interested in consuming these foods.

Poor feeding practice can be caused by a lack of effort related to the involvement of mothers in providing food for the children such as involving children in planning healthy food, giving children the opportunity to choose food, inviting children to cook, making interesting food forms, cooking vegetables, taking children to healthy food shop, and make healthy snacks at home. If the children are involved in the process of preparing, selecting and determining the type of food to be consumed, the child will be familiar with the behavior performed by Mother and begin to develop their ability to choose healthy food for themselves (Dev et al., 2014; Keyle \& Carman, 2014).

The mother's feeding practice is influenced by several factors. These factors include economic factors, social culture, education, environment, mother's age, and family support (Arifin, 2016; Dwi Nugroho et al., 2012; Mohd Nasir et al., 2012; Rakhmawati and Panunggal, 2014).

Economic conditions affect the availability of food served at home. A mother will be able to buy food with good quality and quantity if the family economic conditions meet their daily needs (Arifin, 2016). Research by Rakhmawati and Panunggal (2014) stated that the economic status of the family determined the attitude of the mother towards the selection and proper feeding of children.

Arifin (2016) also stated that the trust factor or culture owned by the community has a great power to influence someone in determining and processing the types of food consumed daily. This causes the culture that is believed by every family to play a role in determining the mother in choosing food for her child. Some parents can avoid certain foods due to the culture they believe in.

The results of the research presented in table 1 showed that the majority of respondents were from junior high school graduates. This educational factor can be a determining factor in 
decision making for a mother's food choices. This is because educational factors related to the knowledge possessed by a mother can determine the way mothers choose food for their children. Mothers who have sufficient knowledge tend to pay more attention to the type of food that suits their children's needs. This is related to the results of research by Rakhmawati and Panunggal (2014) which showed that the lack of mother's knowledge might cause her to pay less attention less in feeding children under five years old.

Handono's research (2010) also supports that the mother's decision to choose food for her child is influenced by a mother's knowledge of the ingredients and types of food. If the knowledge is limited and not extensive, a mother will incorrectly choose the right food for children. A mother's knowledge is also major support of the family economy, food preparation for the family, nurture and care for children. The level of parent's knowledge influences family life, especially the mother's level of knowledge whose role has the greatest influence. This causes a mother to have a big role and responsibility, especially in feeding children (Merita et al., 2017).

A different opinion from Ekawaty, Kawengian, and Kapantow (2015) research which stated that knowledge with nutritional status does not have a significant relationship because mothers who have good knowledge do not necessarily have the ability and expertise in processing and providing the right food for their children. Astuti and Sulistyowati's (2013) study also stated that although mothers have low knowledge he could still take advantage of increasing technological and information developments so that mothers could easily find out information from various media, especially regarding food types and children's food needs to improve their knowledge. This shows that even though the mother has a low level of education if in this modern age she can use technology through electronic media to obtain sources of information related to nutrition properly, she could be able to choose the type of food that contains nutrients according to the needs for the child.

The research result shown in table 1 showed that the highest number of parents were in early adulthood with a range of 26-35 years. According to Hurlock (1994), early adulthood has several developmental tasks such as starting work, choosing a partner, starting to build a family, caring for a child, managing a household, taking responsibility as a citizen and looking for a fun social group. A mother who is undergoing that period has to meet the needs of the child because she has started to build a family. The mother has the role of being the first educator for the child, the first guardian in the life of the child, and the mother is the first example in the child so that the movements and behavior of the mother are always seen by the child. This causes a mother to be able to give an example to consume healthy food so that children can get used to 
and maintain eating behavior to choose healthy and balanced foods according to their nutritional needs (Keyle \& Carman, 2015; Merita et al., 2017).

This is related to the research by Dwi Nugroho et al (2012) which revealed that age factors could influence food choices given to children. As the age increases, the amount of experience that parents have regarding childcare increases which as well is formed from the family environment, especially in terms of proper feeding practices.

Family support in child feeding is related to the parents' role in trying to meet children's eating needs. According to the results of research by Ra, Kalijambe, and Khasanah (2013), the role of parents is very important in feeding children because parents are the facilitators who must be able to guide, assist, and provide food needs for children. Provision of food provided by parents, especially mothers, must consider the value and adequacy of recommended nutrition for children. Support for the provision of food can be realized from the desire of Mother to increase children's growth and development optimally through the fulfillment of child nutrition. According to Murhayani (2015) also explained that if a mother succeeded in doing her role well then it could prove that she had succeeded in meeting nutritional needs through proper feeding for children.

The results of this study showed that the number of poor mother feeding practice category is more than the good category. These results indicate that mothers are still not able to provide proper feeding practice to children in daily life. Seeing these conditions, nurses as health educators must be able to provide information regarding how to feeding practice properly so that children recognize and get used to consuming healthy foods that are good for children's growth and development.

Nurses of the community as a change agent must have the skills to increase maternal awareness, try to change the attitudes and behavior of mothers so that they pay more attention and improve ways of feeding their children, such as restricting foods high in sugar, salt and fat while at school and at home and provide information about the types of foods that contain nutrients that are good for children's health.

Nurses can also play an active role in providing guidance or counseling for mothers to teach strategies that parents could do so children like and recognize healthy food through proper feeding practice.

\section{CONCLUSION}

Mother Feeding Practice for Children aged 3-6 years who attend school in Jatinangor SubDistrict PAUD showed that the number of poor feeding practices categories is more than good categories. These results illustrate that mother feeding practice is still not appropriate in 
fulfilling nutrition for children. Mothers who do not understand information about proper feeding methods could influence the ability of mothers to make decisions about how to provide nutritious food for children and attract children to consume healthy foods according to their age needs.

Researchers suggested to mothers, to pay more attention to the nutritional needs of children so that the nutritional needs of children can be fulfilled according to their age needs so that mothers can improve and maintain the nutritional status of children remain within normal limits. Mothers should also limit foods that contain high sugar, salt, and fat so that they are not consumed by children. Mothers should implement appropriate feeding strategies, children's needs increased so that children need to consume nutritious foods. Nurses also need to carry out socialization in the form of educating mothers regarding proper feeding methods and helping to introduce and understand various nutritious foods (energy, protein, minerals, and vitamins) so that mothers can choose food appropriately according to their needs.

\section{REFERENCES}

Arifin, Z. (2016). Gambaran pola makan anak usia 3-5 tahun dengan gizi kurang di Pondok Bersalin Tri Sakti Balong Tani Kecamatan Jabon -Sidoarjo. Midwiferia, 1(1), 16. https://doi.org/10.21070/mid.v1i1.345.

Astuti, F.D., \& Sulistyowati, T.F. (2013). Hubungan tingkat pendidikan ibu dan tingkat pendapatan keluarga dengan status gizi anak prasekolah dan sekolah dasar di Kecamatan Godean. Jurnal Kesehatan Masyarakat (Journal of Public Health), 7(1), 15-20. Retrieved from http://journal.uad.ac.id/index.php/KesMas/article/view/1237.

Boucher, N.L. (2016). Feeding style and a child's body mass index. Journal of Pediatric Health Care, 30(6), 583-589. https://doi.org/10.1016/j.pedhc.2015.12.002.

Braden, A., Rhee, K., Peterson, C.B., Rydell, S.A., Zucker, N., \& Boutelle, K. (2014). Associations between child emotional eating and general parenting style, feeding practices, and parent psychopathology. Appetite, 80, 35-40. https://doi.org/10.1016/j.appet.2014.04.017.

Dev, D.A., McBride, B.A., Speirs, K.E., Donovan, S.M., dan Cho, H.K. eu. (2014). Predictors of head start and child-care providers' healthful and controlling feeding practices with children aged 2 to 5 years. Journal of the Academy of Nutrition and Dietetics, 114(9), 1396-1403. https://doi.org/10.1016/j.jand.2014.01.006.

Doaei, S., Kalantari, P.N., Gholamalizadeh, P.M., \& Rashidkhanip, P.B. (2013). Validating and investigating reliability of comprehensive feeding practices questionnaire. ZJRMS, 15(3), $42-45$.

Dwi Nugroho, B.F., Endah, S., \& Ernawati, Y. (2012). Karakteristik perilaku pemberian makan dan status gizi anak usia 1-3 tahun di Posyandu Kuncup Melati Puskesmas, 297-304.

Ekawaty, M., Kawengian, S., \& Kapantow, N. (2015). Hubungan antara pengetahuan ibu 
tentang gizi dengan status gizi anak umur 1- 3 tahun di Desa Mopusi Kecamatan Lolayan Kabupaten Bolaang Mongondow Induk Sulawesi Utara. Jurnal E-Biomedik (EBM), 3(2), 609-614.

Febry, A.B., \& Marendra, Z. (2008). Buku pintar menu balita. Jakarta: PT Wahyu Media.

Gibson, E.L., Kreichauf, S., Wildgruber, A., Vögele, C., Summerbell, C.D., Nixon, C., ... Manios, Y. (2012). A narrative review of psychological and educational strategies applied to young children's eating behaviours aimed at reducing obesity risk. Obesity Reviews, 13(SUPPL. 1), 85-95. https://doi.org/10.1111/j.1467-789X.2011.00939.x.

Handono, N.P. (2010). Hubungan tingkat pengetahuan pada nutrisi, pola makan, dan energi tingkat konsumsi dengan status gizi anak usia lima tahun di Wilayah Kerja Puskesmas Selogiri, Wonogiri. Jurnal Keperawatan, 1(1), 1-7.

Hurlock, E.B. (1994). Psikologi perkembangan, suatu pendekatan sepanjang rentang kehidupan. Jakarta: Erlangga.

Judistiani, R.T.D., Fauziah, A., Astuti, S., Yuliani, A., \& Sari, P. (2015). Gangguan gizi balita di Desa Mekargalih Kecamatan Jatinangor - Sumedang. Jurnal Kesehatan Masyarakat, 1(38), 84-91.

Kementerian Kesehatan RI. (2016). Kementerian Kesehatan RI 2016. Retrieved from http://www.kesmas.kemkes.go.id/assets/upload/dir_519d41d8cd98f00/files/Buku-SakuHasil-PSG-2016_842.pdf.

Kementerian Kesehatan RI. (2017). Kementerian Kesehatan Republik Indonesia. Retrieved from http://www.depkes.go.id/article/view/16111500002/germas-wujudkan-indonesiasehat.html.

Keyle, T., \& Carman, S. (2014). Buku ajar keperawatan pediatrik (Edisi 2, Volume 1). (S. K. Estu Tiar, S.Kep, Ns. Sari Isnaeni, S.Kep, \& Ns.Barrarah Bariid, Ed.) (2nd ed.). Jakarta: EGC.

Keyle, T., \& Carman, S. (2015). Buku praktik keperawatan pediatri. Jakarta: EGC.

Merita, Sari, M.T., \& Hesty. (2017). The positive deviance of feeding practices and carring with nutritional status of toddler among poor families. Jurnal Kesehatan Masyarakat, 13(1), $106-112$.

Mohd Nasir, M.T., Norimah, A.K., Hazizi, A.S., Nurliyana, A.R., Loh, S.H., \& Suraya, I. (2012). Child feeding practices, food habits, anthropometric indicators and cognitive performance among preschoolers in Peninsular Malaysia. Appetite, 58(2), 525-530. https://doi.org/10.1016/j.appet.2012.01.007.

Murhayani, P.W. (2015). Hubungan kontrol makanan, model peran dan keterlibatan anak dengan sulit makan pada anak. Jurnal Keperawatan Sriwijaya, 2(1), 8-21.

Musher-Eizenman, D., \& Holub, S. (2007). Comprehensive feeding practices questionnaire: validation of a new measure of parental feeding practices. Journal of Pediatric Psychology, 32(8), 960-972. https://doi.org/10.1093/jpepsy/jsm037.

Ningsih, S., \& Kristiawati, I.K. (2015). Hubungan perilaku ibu dengan status gizi kurang anak 
usia toddler. Jurnal Pediomaternal, 3, 58-65.

Perdani, Z.P., \& Hasan, R. (2016). Hubungan praktik pemberian makan dengan status gizi anak usia 3- 5 tahun di Pos Gizi Desa Tegal Kunir Lor Mauk. Jkft, 2(August), 17. Retrieved from https://jurnal.umt.ac.id/index.php/jkft/article/view/59/40.

Ra, T.K., Kalijambe, G., \& Khasanah, R.N. (2013). Hubungan peran orang tua sebagai fasilitator pemberian asupan makanan dengan status gizi pada anak pra sekolah TK/RA Guppi 1 Kalijambe Sragen, 1-11.

Rakhmawati, N.Z., \& Panunggal, B. (2014). Hubungan pengetahuan dan sikap ibu dengan perilaku pemberian makanan anak usia 12-24 bulan. Journal of Nutrition College, 3(1), 43-50.

Riskesdas. (2013). Riset Kesehatan Dasar (RISKESDAS) 2013. Laporan Nasional 2013, 1-384. https://doi.org/1 Desember 2013.

Sholikah, A., Rustiana, E.R., \& Yuniastuti, A. (2017). Faktor - faktor yang berhubungan dengan status gizi balita di pedesaan dan perkotaan, 2(1), 9-18.

Soenardi, T. (2005). Seri menu anak variasi makanan balita. Jakarta: PT Gramedia Pustaka Utami.

Subarkah, T., Nursalam, \& Rachmawati, P.D. (2016). Pola pemberian makan terhadap peningkatan status gizi pada anak usia $1-3$ tahun (Feeding pattern toward the increasing of nutritional status in children aged $1-3$ years). Jurnal INJEC, 1(2), 146154.

Sutomo, B., \& Anggraini, D.Y. (2010). Menu sehat alami untuk batita dan balita. Jakarta: Demedia.

Waladow, G., Warouw, S.M., \& Rottie, J.V. (2013). Hubungan pola makan dengan status gizi pada anak usia 3-5 tahun di Wilayah Kerja Puskesmas Tompaso. Ejournal Keperawatan, 1(1), 1-6. 